\title{
Exploring Ethnomathematics with Ethnomodeling Methodological Approach: How Does Cigugur Indigenous People Using Calculations to Determine Good Day to Build Houses
}

\author{
Uba Umbara ${ }^{1,2^{*}}$, Wahyudin Wahyudin ${ }^{2}$, Sufyani Prabawanto ${ }^{2}$ \\ ${ }^{1}$ Department of Mathematics Education, STKIP Muhammadiyah Kuningan, Kuningan, INDONESIA \\ 2 Department of Mathematics Education, Universitas Pendidikan Indonesia, INDONESIA
}

Received 25 March 2020 - Accepted 10 January 2021

\begin{abstract}
This article discusses Cigugur indigenous communities' custom in carrying out calculation practices to determine the best time to start house construction activities. The realist ethnography approach was used in this study through exploratory research. The ethnomathematics design adopted four elements: generic questions, initial answers, critical constructs, and specific activities. Ethnomodelling was used to translate cultural mathematics ideas into academic mathematics through ethical, emic, and dialogical approaches. Based on ethnomathematics, the community practices the dimensions of necessary universal mathematical activities, such as counting, placing, and explaining. Based on ethnomodeling, mathematical ideas and practices carried out are relevant to the concepts of enumeration, integer operations, sets, relations, congruence, and modulo. The study results recommend the importance of ethnomodelling as a methodological approach to ethnomathematics to create and develop didactical situations, especially in developing a new lesson.
\end{abstract}

Keywords: culture, ethnomathematics, ethnomodeling, mathematical ideas, mathematical modeling, mathematical practice

\section{INTRODUCTION}

One of the many tribes in Indonesia is the Sundanese. Based on historical data, Sundanese first appeared in the IX century AD. The term Sunda refers to understanding the region in the western part of Java Island (West Java Province and Banten Province) with all human life activities. As a tribe, Sundanese is also closely related to culture, mainly characterized by Sundanese language usage. Sundanese culture lives grow and develop among the Sundanese people who generally live in the Sunda Land (Ekajati, 1995). However, as the times of the Sundanese tribe have experienced cultural acculturation. It is not easy to conduct ethnographic studies of most Sundanese people with an extensive area and classified as a moderate society. One way that can be done is to conduct a study on Sundanese indigenous communities who still hold culture for generations. In this study, the Cigugur Traditional Village was chosen as the object of study. Indigenous communities are chosen based on consideration of their cultural peculiarities compared to other communities' cultures. The Cigugur community holds the principle" walau tidak sepengakuan tapi sepengertian" (although not as acknowledgment but understanding).

The principle underlies the Cigugur indigenous community's life so that it highly upholds harmony, mutual respect, and mutual respect between one another. The Cigugur indigenous community cannot be separated from Sundanese cultural roots because it is part of the Sundanese ethnic community, culturally, historically, and geographically. The Cigugur indigenous community's character is mostly the same as the Sundanese people in general, including in their mathematical practice. The Sundanese are accustomed to using mathematics as a calculation tool in their daily activities; farmers determine planting time; traders use a single size; fishermen predict tidal seawater; carpenters use symbolic measures; and others (Abdullah, 2017). The practice of mathematics carried out by the community is

(C) 2021 by the authors; licensee Modestum. This article is an open access article distributed under the terms and conditions of the Creative Commons Attribution License (http://creativecommons.org/licenses/by/4.0/).

\uba.bara@upmk.ac.id (*Correspondence) $\$ wahyudin.mat@upi.edu $\$ sufyani@upi.edu 


\section{Contribution to the literature}

- This article discusses ethnomathematics studies conducted on indigenous peoples. The results of the study provide evidence that cultural mathematics has shown its existence and development.

- This article discusses the relevance of academic mathematical concepts to cultural mathematics through mathematical modeling. It is identified based on ethnomodeling as an alternative approach in ethnomathematics. This ethnomodeling needs to focus on ethnomathematics' attention and development.

- This article is expected to raise awareness about the importance of ethnomodeling as a pedagogical approach that serves to describe the modeling process and phenomena in local cultural systems with academic representation and translate cultural mathematics into mathematics based on ethical, emic, and dialogical approaches in creating and implementing didactic situations in shaping pedagogical tools mathematics learning by promoting aspects of culture.

a form of mathematics in everyday life closely related to ideas, thought processes, and the value of mathematics itself.

The value of mathematics is related to the nature of mathematics inherited by diverse cultural mathematicians in developing mathematics (Bishop, 1999). Mathematics is the knowledge of a culture that grows and develops according to human needs (Knijnik, 1993); based on the classification of mathematical objects consisting of direct objects and indirect objects (Gagne, 1983). Direct objects include facts, concepts, principles, and skills. In contrast, indirect objects include thinking logically, solving problems, being positive, diligent, conscientious, cooperative, and honest, leading to student character formation (Umbara et al., 2019). Procedurally mathematics can be defined as the art of thinking, reasoning, communicating, and representing various concepts and ideas related to quantitative values in everyday life both as individuals and society members. The general view of mathematics as a tool is believed to describe individuals' importance with mathematical knowledge. The general view of mathematics as a tool is believed to be able to describe the importance of individuals having mathematical knowledge (Umbara \& Suryadi, 2019) so that the need to interpret the uniqueness, uniqueness, complexity, and originality of mathematical thinking is an invaluable art contained in the values and nature of mathematics itself.

On the other hand, since centuries ago, mathematics was believed and interpreted as a universal concept. The universality of mathematics can be interpreted as a unity of concepts that apply equally and consistently in any earth's hemisphere. The fact that mathematics is found worldwide, in various places, and at different times with little or no contact between its creators reinforces the notion of the universality of mathematics (Yusuf et al., 2010). This belief arises because some theorems and propositions in mathematics can be generalized to apply universally by setting aside ethnological boundaries. This fact cannot be denied on one side, such as symbols, notations, logic, principles, theorems, assumptions, and others that are agreed upon and generally accepted.
Thus, in studying mathematics, a person is often trapped in a formal process with strict and rigid rules (Umbara \& Suryadi, 2019).

Beliefs about the universality of mathematics have a strong foundation. This conviction is seen based on facts about identical concepts and basic premises found throughout the world (Wahyudin, 2018). However, anthropologists have shown various evidence of typical mathematical activities carried out by the community, such as counting, sorting, measuring, weighing, and sorting done in ways very different from the material taught in schools (D'Ambrosio, 1997). Thus, the initial conclusion of what is being debated is that although various propositions, axioms/postulates, assumptions, traits, and theorems apply universally, the methods of achievement and usefulness are influenced by culture. The universality of mathematics is felt not to apply when mathematics is confronted with applying ideas, ideas, concepts, values, and the nature of mathematics based on a particular society's culture. Cultural values can influence education in general and mathematics education in particular (Fouze \& Amit, 2017).

The initial conclusion seems to be a firm reference to the role of culture as a conductor in the evolution of mathematics education, especially related to the values and nature of mathematics itself. Mathematical values and nature will remain in their form to be maintained and developed as an inseparable part of realizing mathematics's ideals. Understanding the universality of mathematics leads to the independence of the value of mathematics itself. Thus, the view emerges that mathematics is free of values and culture, but mathematics simultaneously forms and shapes human groups' various values and beliefs (Wahyudin, 2018). On the other hand, according to Keitel et al (1989), many countries have been concerned about the importance of justice in mathematics education, especially regarding subjects considered free of values and culture. Many mathematical educators' views state that there is no need to consider the growing student population (Presmeg, 1998). 
These concerns become a reference in laying the foundation of the importance of recognizing the mathematical way of thinking of each person who has a different culture, so the role of mathematics cannot be separated from the development of the culture itself. Mathematics originally came from various cultures and could be a source of inspiration for students from their own culture (Lesser, 2006). From this view, we believe that mathematics is closely related to culture. It becomes a conclusion that cannot be denied, primarily related to their respective roles. In other words, it can be said that mathematics can produce and be produced from various forms of culture. This conceptual framework encourages several studies on the evolution of mathematical concepts in culture and anthropology by making a bridge between anthropologists, cultural historians, and mathematicians to recognize differences in thinking, leading to various mathematics forms. This field is called Ethnomathematics (D'Ambrosio, 1985).

Based on the initial study results, it is suspected that several ideas, processes, symbols, and forms involve mathematical activities in the Cigugur indigenous community's daily life. Therefore, researchers intend to explore the forms of mathematical concepts used based on the perspective of ethnomathematics. The ethnomathematics study results on the Cigugur indigenous community can enrich the previous ethnomathematics study conducted on agriculture. Research about Cigugur indigenous farmers' community has also practiced ethnomathematics in determining good days for planting rice (Umbara et al., 2019). Besides, the Banten Province's Baduy weaving process in Indonesia uses their ability to measure, compare, add, subtract, multiply, and divide even though they have never studied in traditional schools (Turmudi et al., 2016), and the Aboge calendar is used in determining the holidays at the palace Kasepuhan Cirebon, West Java Province of Indonesia (Syahrin et al., 2016).

These studies were conducted on a group of people who are an integral part of the Sundanese community. In general, Sundanese is accustomed to mathematical calculations, modelling, and predicting phenomena using symbolic mathematical calculations consisting of basic units, length, width, area, height, weight, group, and time (Abdullah, 2017). On the other hand, Sundanese people's cultural activities are also carried on from generation to generation, including estimating, patterning activities, and building geometric patterns (Muhtadi et al., 2017). At another level, ethnomathematics studies have been carried out by international researchers who researched certain ethnic groups or community groups, such as the Incas (Ascher \& Ascher, 1986); children in a slum city in Brazil (Borba, 1987); carpenters in Cape Town, South Africa (Millroy, 1992); farmers and fishers in Mozambique (Gerdes, 1998); Hausa tribe in Nigeria (Yusuf et al., 2010);
Kabihug tribe in the Philippines (Rubio, 2016), karara weavers in Maranao (Solaiman \& Manalundong, 2017).

Practically and empirically, these studies can reveal practices in the form of ethnomathematics that are different from each other both in one group and in different groups of people. This study focused on using mathematical concepts, principles, ideals, and values in the Cigugur Indigenouscommunity's life, especially in determining the excellent day to start constructing their residential buildings. The mathematics practices that they do are considered to have exclusive value compared to other Sundanese people. For this reason, it seems that the study of mathematical practices that are still maintained and carried out as a tradition can be explored in-depth, both in identifying fundamental mathematical values used and in identifying mathematical concepts and procedures based on ethnomodelling research.

Ethnomodelling is an alternative methodological approach that can be considered a practical application of Ethnomathematics (Rosa \& Orey, 2011), It is bound by cultural forms and mathematical modelling (D'Ambrosio, 1990), to contribute to acquiring a complete understanding of mathematical practices developed by members of cultural groups (Rosa \& Orey, 2012). Ethnomodelling can bridge mathematical ideas and practices based on academic mathematics's cultural aspects to erode or eliminate the blurring of mathematical concepts. Ethomodelling can be used to describe the process of modelling a local cultural system (emic) with a global representation of Western academics (etic), and its translation is done through a dialogical process (Rosa \& Orey, 2012).

Thus, there are three alternative approaches to research ethnomodelling: emic, etic, and dialogical. Emic is used to understand mathematical ideas, procedures, and practices developed by members of cultural groups. It can be a source of inspiration for etic hypotheses. While etic (used in comparing between components of crosscultural ethnology to facilitate communication), and dialogical (a process of dialogue and interaction between the traditions of emic knowledge and etic), so that the three can define mathematical phenomena in a culture (Rosa \& Orey, 2012). Thus, the use of the ethnomodelling approach in this study is expected to be able to describe various problems in the practical context of culture through the researcher's critical analysis to determine the ideal version of the mathematical concepts used by the indigenous Cigugur community by examining, studying, understanding, and explaining the mathematical reality used in everyday life at that.

This study focuses on the Cigugur indigenous people's habits in counting the good days, which will be used as a reference in starting house construction. Therefore, this study demonstrates the Cigugur indigenous people's activity in counting as a unique and 
exclusive habit. This uniqueness and exclusivity is a calculation activity that is used to make predictions about an event. Based on this, this research will be guided by the following questions: (1) What are the procedures used by indigenous peoples in determining the excellent day to build a house ?; (2) What mathematical concepts are used by the Cigugur indigenous people in calculating the perfect day?; (3) What mathematical concepts can be adopted into mathematics learning in schools? Researchers' success in carrying out ethnomathematics studies with an ethnomodeling approach can strengthen the school mathematics learning curriculum's development. The application of ethnomathematics practice with the ethno-modeling approach can recontextualize an approach that focuses on culture-based learning.

\section{LITERATURE REVIEW}

\section{History and Philosophical of Ethnomathematics}

The long history of mathematics and mathematics education is inseparable from the composition of Roman, Greek, and Egyptian history. Most mathematics relies on ancient traditions of Mediterranean civilization (D'ambrosio, 1995), so the historical review's tendency to make mathematics adapted and given place as practical scientific mathematics or academic mathematics taught in most schools today ( $\mathrm{D}^{\prime}$ Ambrosio, 1985). This concept makes boxed mathematics because it can eliminate disparities in mathematics practiced outside the historical composition. Meanwhile, mathematics learning cannot be denied carried out by involving social, cultural, and cognitive phenomena in an integrated way (Schoenfeld, 1989). Ethnomathematics then emerged as a field of study that emphasized mathematical conceptuality more broadly by identifying mathematical practices carried out by societies of different cultures without discrediting certain cultures. It arises because of the awareness that mathematics is practiced in various cultures.

Ubiratan D'Ambrosio first proposed the concept of ethnomathematics in 1977 (Vasquez, 2017). Ethnomathematics was born from debates in several studies, books, and scientific forums in international mathematics education. The facts related to the development of ethnomathematics as a field of research are described in six stages (Rosa \& Orey, 2005), as follows: (1) In 1973 Zaslavsky published a book entitled "Africa Counts: Number and Patterns in African Culture" which explores the history and practice of mathematical activities in the Sahara African community (Zaslavsky, 1994); (2) in 1976, it was implemented "Third International Congress of Mathematics Education" in Karlsruhe, Jerman which is chaired by D'Ambrosio with a theme "Why Teach Mathematics?"; (3) In 1977 $\mathrm{D}^{\prime}$ Ambrosio introduced the term ethnomathematic at an annual meeting American Association for the
Advancement of Science, di Denver, Amerika Serikat; (4) in 1984 the term consolidated "ethnomathematics" by D'Ambrosio in Adelaide at the opening "Fifth International Congress of Mathematics Education"; (5) In 1985 D'Ambrosio published a paper entitled "Ethnomathematics and its Place in the History and Pedagogy of Mathematics"; (6) In 1985, the launching of the Ethnomathematics Program was established International Study Group on Ethnomathematics (ISGEm).

However, long before that, the issue of mathematical position in cultural anthropology had come to experts' attention. So, it is not wrong to mention that ethnomathematics was pioneered earlier by mathematicians, psychologists, and ethnographers in the 1940s and 50s, especially by R. Wilder [1950], L. White [1947], E. Fettweis, G. Luquet [1929], and O. Raum [1938] as the forerunners of isolated ethnomathematics so that their appearance is slower than other ethnoscience (Gerdes, 1996). Long before that, the term 'original mathematics' was introduced to criticize western-oriented education in Liberian schools, with the primary aim being that students could see the importance of what they were learning according to their character, environment, culture, and daily life (J. Gay \& Cole, 1967). The study highlights aspects of language used in perceiving various types of mathematical operations, discusses the everyday understanding of words used in mathematical problems, and shows various relevant aspects of the Kpelle language viewpoint. Thus, awareness emerged in the importance of using cultural aspects in learning carried out by mathematics teachers in Liberia.

In this context, ethnomathematics based on various concepts has been proposed that contrast with academic mathematics/school mathematics by experts and previous researchers, including indigenous mathematic, Sociomathematics of Africa, informal mathematic, mathematics in the (African) sociocultural environment, spontaneous mathematics, oral mathematic, oppressed mathematic, non-standard mathematics, hidden or frozen mathematic, folk mathematic, dan mathematics codified in know-hows (Gerdes, 1994). Based on his replication, Gerdes stated that the proposals were temporary and did not find much echo. However, these aspects had been gradually united to become more familiar with the term ethnomathematics by D'Ambrosio in 1985 through the International Study Group on Ethnomathematics (ISGEm).

Awareness about social and cultural aspects in mathematics and mathematics education among mathematicians becomes a formal aspect that provides space for the emergence of the concept of ethnomathematics. Cultural aspects are felt to occupy a central role in mathematical concepts, especially to solve real-world problems. In this case, it cannot be denied that the development of mathematical concepts and 
ideas starts from the real world, although it is not entirely true. Philosophically, mathematics is a structural process that is not permanent and is produced through social contexts. For this reason, interactivity and connectivity between the diversity of cultural entities and logical rationality can be used to present various definitions and inferences in expressing mathematical structures. Rationality is needed in communicating ideas between cultures because mathematics and logic develop from imitation or standardization of rationality itself. Analysis of cultural influences on mathematics is needed to show the diversity of cross-cultural mathematical knowledge (Galperin \& Georgiev, 1969). The process of identifying, generalizing, and formulating mathematical problems might be hampered if a process of adaptation to culture does not precede it.

Based on this historical study, we can build an initial conclusion that ethnomathematics can be interpreted as a set of mathematical traditions and practices to believe mathematics is created from rationality that is culturally taken as an absolute fact. Although various mathematical assumptions and theorems are universal, their application, use, and even the methods used to study them appear to be influenced by cultural entities and identities (Wahyudin, 2018). Ethnomathematics survive and develop based on community needs in individual and social relationships. Internal revolutions in ethnomathematics are the result of changes in society as a whole. However, the chain of the historical development of knowledge structured as a scientific discipline cannot be recognized so that ethnomathematics is not recognized as a body of structured knowledge but only as a set of temporary practices (D'Ambrosio, 1985).

Ethnomathematics in history and pedagogy emphasizes the broad conceptualization of mathematics so that its existence can be identified through several mathematical practices (Ernest, 1991). Ethnomathematics exploration can open space about a society's mathematical activities carried out in a certain period both in the past, present and future continuously, simultaneously, and continuously. Critical thinking about ethnomathematics is based on thought, reasoning, and information processing in the human cognitive structure of mathematical and cultural concepts (Umbara et al., 2019). So, a question arises whether ethnomathematics can be categorized as a science that meets the truth ?. These questions can be traced based on philosophical studies, at least viewed based on ontological, epistemological, and axiological.

Based on ontological aspects, ethnomathematics' objects can be adequately explored and closely related to human comprehension (thinking, feeling, and sensing). One form of ethnomathematics can be identified based on broad ethical concepts, such as codes, symbols, jargon, myths, and ways of thinking in making remarkable conclusions (D'Ambrosio, 1985). At a glance, ethno objects in a simple form may not appear to contain mathematical concepts. Nevertheless, studying various aspects of daily activities, thinking (logical ideas and intuition), artipact even naming several objects can be objects and tools in exploring ethnomathematics. In principle, ethnomathematics study's object depends on how the researcher analyzes mathematical ideas that arise in a community.

Artifact can be simple tools in mathematical tools with a few modifications, such as analyzing the artefacts' data (Bonotto, 2007), thus creating new goals and actual experiences in mathematical modelling (Turmudi, 2018). Examples of artifact and naming of several objects found in the Gilbert Islands Republic of Kiribati have 18 number classifiers, some of which are living objects and spirits, assemblages of people, days, years, generations, coconut fronds, fronds, fringes of objects (other than midribs), customs, modes of transportation. (Ascher, 1991); hand-woven baskets or textiles, ships, rulers, or even systems for recording numerical information as in 'quipu' (Palhares, 2010). Meanwhile, concrete examples of a cultural community's daily activities and thoughts can be drawn from the Yuki in California. They think of an eight-based system. The eight-based Yuki tribal system is the most logical reason based on the amount of space between fingers (Wahyudin, 2018).

Epistemologically, ethnomathematics can be viewed based on the nature of knowledge, justification, and beliefs' rationality. The truth of ethnomathematics as a field of study can be carried out following standard processes and procedures, including strategic schemes that guide ethnomathematics research. The scheme can be arranged by describing the strategy and rationale (Millroy, 1992). The strategy can be recognized when researchers can describe the cultural activities of society that contain mathematical values. This strategy is reflected in the activities of a group of people in constructing mathematical ideas. A study shows how to count numbers carried out in different ways using fingers (Zaslavsky, 1991). So, thinking in ethnomathematics based on the process and obtaining the truth of ethnomathematics must be clarified based on how to communicate mathematical ideas and how mathematics is socially constructed.

Based on axiological studies, ethnomathematics as knowledge must meet the aspects of usefulness related to how to use and moral rules that grow on the broader community. This section presents the importance of exploring ethnomathematics based on complete mathematical rationality and different cultural rationalities. The integration of these two rationalities is a tool that can be used in studying cross-cultural mathematics so that the studies conducted are constant. Rationality is needed for intercultural communication because mathematics and logic develop based on imitation or standardization of a form of rationality that can help a community form mathematical foundations 
(Wahyudin, 2018). It was done as an effort to describe the value and nature of ethnomathematics itself so as not to cause research bias. Based on axiological studies, a study shows a construction method of "rectangular bases" that are commonly used among Mozambican farmers in Africa (Gerdes, 2001). The study was produced based on a study of most Africans in southern Sahara. Traditionally the community was able to build houses on a circular or rectangular basis.

The phenomenon is proof that ethnomathematics provides benefits both technically and tactically for the community. Community activities in a cultural environment generate brilliant mathematical thoughts and ideas to meet their needs. Awareness about the importance of this study becomes an integral part of ethnomathematics research. If the ontological, epistemological, and axiological aspects are welldescribed, the mention of ethnomathematics as part of a study in mathematics education research meets the element of proof of truth as science. On the other hand, we need to realize that mathematics's main foundation is logical. Logical thinking is an ideal way of thinking, where logic is always associated with systematic management and inferential reasoning so that logic is seen as the antithesis of self-whispering, inspiration, artifact, and intuition (Wahyudin, 2018). However, logical thinking tends to make humans think rigidly by eliminating the spontaneous element of thinking.

The research conducted by Gerdes, as previously explained, can also be used as an example of how intuition acts as a catalyst for the formation of a mathematical, logical thinking foundation of society. The rectangle that Mozambican farmers can build starts without building one right angle at a time (Gerdes, 2001). Based on this, a priori can be believed that intuition is fundamental to find mathematical concepts. Thus, intuition can be said to be the prompter that laid the foundation for the creation of logic and mathematics. Intuition arises when humans are confronted with the importance of solving problems and meeting their daily needs. So pragmatically, the main reason underlying mathematical development patterns through the transmission and distribution of mathematical knowledge to help people solve problems in their daily reality (Francois \& Kerkhove, 2010). Based on the historical and philosophical review, it can be concluded that ethnomathematics as a field of study deserves to be called a science that is bound by the search for truth.

\section{Definition and Generalization of Ethnomathematics}

As a field of research studies, ethnomathematics is proven to provide historical, philosophical, theoretical, practical, technical, and empirical evidence that is convincing that various forms of mathematical ideas and practices result from the diversity of people's thinking in a group or across cultures. These arguments do not appear to have an impact on standard definitions for constructing the term ethnomathematics specifically. Some of the definitions that appear are feared to confuse ordinary people so that systemically may be able to hamper the ability to understand them. Understanding the standard definition of ethnomathematics can be an entry point for teachers and researchers to explore forms of ethnomathematics. So the importance and relevance in mathematics and mathematics education have a strong foundation. The importance and relevance of ethnomathematics as an exciting issue and field of study academically have been arranged theoretically and historically by several experts (Borba, 1990); (D'Ambrosio, 1997); and (Powell \& Frankenstein, 1997).

This section discusses the definition and shift in ethnomathematics' meaning from simple definitions to more general definitions. An explanation of the shift in meaning is expected to provide information on the development of ethnomathematics studies, which emerged based on practical and theoretical studies empirically. Ethnomathematics is defined as the study of mathematical concepts on a small scale or indigenous culture (Eglash, 1997) or how Ascher \& Ascher (1997) define ethnomathematics as the study of mathematical ideas from people who cannot read and write (Powell \& Frankenstein, 1997). This definition, considered too simple by some experts, is too narrow to be able to open generalized research related to the topic of ethnomathematics (Wahyudin, 2018), thus suggesting that mathematics which is seen as integrated with cultural elements occurs when discussing mathematics from people who cannot read and write (Borba, 1990). The study of ethnomathematics is limited by only providing space for study in primitive people living in rural tribes or for a group of people who have never studied mathematics formally. Based on this perspective, mathematics will only last with the stigma that mathematics is only owned by formal and educated people.

However, this definition provides a firm reference to the essential elements needed in the study of ethnomathematics. The two most essential elements needed to express ethnomathematics embedded in cultural activities are experts in mathematics and people from a culture who do not understand mathematical researchers (Barton, 1996). The formal structural metamorphosis and deductive methods in mathematics are indeed constructed based on the diversity of crosscultural mathematical practices. It is based on Saunders Mac Lane (1981) saying that mathematics begins with a variety of human life activities in disentangles, several ideas are then derived, but not just any of them are formalized so that mathematics learns formal structures with deductive methods (Barton \& Frank, 2013).

On the other hand, anthropologists who pay attention to ethnomathematics suggest that mathematical knowledge must be based on the stigma of 
mathematical consistency obtained through exploration, discovery, regular and average symbols, transmission, and sharing between cultures (Gerdes, 1996). Meanwhile, Barton suggests describing mathematical knowledge as a human knowledge system for understanding numbers, relationships, and spaces encountered so that mathematics is closely related to social culture (Turmudi, 2018). It is in line with the six dimensions of necessary universal mathematical activities: counting, placing, measuring, designing, playing, and explaining (Bishop, 1991). The activity is the original and dominant context owned by a community, although we may encounter differences in their native language.

When mathematics is seen in cultural anthropology, it can produce at least two basic concepts about the form of mathematics learned with known mathematics. There is a difference between mathematics being studied, and someone knows mathematics because not all mathematics can be applied in daily life (Ojose, 2011). Both concepts are the general form to distinguish between academic mathematical concepts and practical mathematical concepts. Awareness about conceptuality has long been realized, significantly when the emergence of the previous terms before the term ethnomathematics, a priori believed to be fundamental intuition in finding mathematical concepts.

We believe that conceptuality is the primary consideration for most experts to describe and give meaning to ethnomathematics, including shifting their perspective. This conceptuality has encouraged the study of the evolution of mathematical concepts in a cultural and anthropological framework, to be able to make a bridge between anthropologists, cultural historians, and mathematicians aiming to recognize the different ways of thinking of various mathematical forms (D'Ambrosio, 1985). Evolution in this framework means integrating the three fields mentioned by focusing on each of these fields' slices. It underlies a shift in the meaning of Ethnomathematics that Ascher \& Ascher previously described. Ethnomathematics is then accepted based on a derivation process consisting of three basic lexical units forming a new lexeme (the smallest word unit). In linguistics, the derivation is the process of forming words into new words and producing special meanings. The concept of derivation is a syntactic rule that is not automatic and systematic but is optional and sporadic to change the lexical identity (Katamba, 1993). It is characterized by the presence of prefixes and suffixes from the main elements.

The concept of derivation is used to give meaning to ethnomathematics, lexically consisting of ethno prefixes, suffix tics, and mathema as the main subject. Ethno prefixes consist of elements (natural, social, cultural, and imaginary environment) which are accepted as a broad term referring to the sociocultural context (consisting of language, jargon, code, behavior, myths, and symbols) that refers to group identification cultural groups and specific ways used to reason and conclude. Lexical mathema derivation as the main element of mathema lexeme tends to be challenging to define as explaining, knowing, understanding, and doing activities (encoding, measuring, classifying, ordering, inferring, and modelling). Suffix tics come from engineering and have the same roots as art, fashion, style, and technique (D'Ambrosio, 1990).

The meaning can be seen as an inauguration of the term more moderate ethnomathematics and deliver it at the culmination point because it can eliminate the shadow of some vague meanings. As a process, ethnomathematics is then described as a set of slices between cultural anthropology, institutional mathematics, and mathematical modelling that can be used to solve real-world problems (Orey \& Rosa, 2006). Meanwhile, the scope of people or cultural groups in the practice of ethnomathematics which is broader than described as indigenous peoples, urban and rural communities, labour groups, groups of children based on a certain age, professional class, and other groups that can be identified through objects and tradition (D'ambrosio, 2016). The integrity of meaning and clarity regarding various groups' configuration gives the impression that the definition of ethnomathematics is restrictive.

The meaning of ethnomathematics is based on the process and scope, then develops because it is culturally possible to experience acculturation. This definition is needed for the need for more complex cross-cultural studies. Thus, ethnomathematics is claimed to handle comparative studies of mathematics from various cultures, especially about how mathematics has shaped, and in turn, shaped by various values and beliefs of human groups (Hammond, 2000). This definition provides a strong foundation for studying various crosscultural ethnomathematics due to acculturation and natural variations in human culture that develop from social processes. It also reflects the growing awareness of the diversity of mathematical activities and cultural communities' diversity (Gerdes, 2001). The flexible definition of ethnomathematics has a shift in meaning from ethnomathematics itself, but this does not mean a negative stigma for the development of ethnomathematics as a field of study.

This shift in meaning provides room for everyone to contribute to the development of research in this field. So the most important thing is not to question the embedding of meaning but to understand ethnomathematics as a study that will continue to develop and contribute to ethnographic research. The vital meaning of ethnomathematics can provide a strong foundation maintained in future research developments. Mathematics not only produces culture, but it is also produced by culture. It is essential to include the mathematical contributions of all cultures (Knijnik, 
2007); the scope of research on ethnomathematics is no longer limited to the traditional scope of human culture and includes historical and realistic, macro and micro research (Zheng, 1999).

Ethnomathematics is expected to have the capacity to support the mathematics evolution in terms of both values and characteristics. Ethnomathematics has an essential character as a transformational effort because changing understanding of mathematics can help develop various mathematical concepts (Orey \& Rosa, 2006), identifying mathematical problems starting from other knowledge in its form and rationale (Domite, 2004). Ethnomathematics, as a conductor of the evolution of mathematical concepts within the framework of cultural anthropology, can place mathematics in a conceptuality oriented towards social evolution. As a complete form, ethnomathematics maintains its own lives and develops due to changing society (D'Ambrosio, 1985), which belongs to the unity of context. The context is the original context that is owned, maintained, and developed by a community. So ethnomathematics can be interpreted as a slice between the context authenticity, social and cultural activities of the community with the mathematical concept.

\section{Ethnomodeling as a Transformation of the Ethnomathematics Program}

Practically and empirically, ethnomathematics research can express mathematical ideas and concepts of a cultural group that is different from one another. Researchers who use their research findings are empirical evidence supporting the relativity and history of particular mathematical culture (Cimen, 2014). Researchers who are experts in mathematics and people from a culture who practice habits are essential in expressing Ethnomathematics (Barton, 1996). However, in expressing mathematical ideas and concepts in a cultural group, researchers sometimes find it difficult to understand mathematical ideas, ideas, procedures, and practices that have arisen in society.

Researchers' difficulties arising from the methodological approach's limitations and the framework that lies in adapting the form of ethnomathematics into the mathematics curriculum are real problems faced by ethnomathematics researchers. Another difficulty in ethnomathematics research lies in adapting the form of ethnomathematics into the mathematics curriculum. However, both difficulties are allegedly anticipated through ethnomodelling as a methodological approach in ethnomathematics research. Ethnomodelling was introduced by Rosa and Orey in 2013 , based on her experience in a program called " $O$ Museu Aberto" (Rosa \& Orey, 2013b). Through the use of ethnomodeling, ethnomathematics researchers have a great opportunity to find and use mathematical modeling in their research.
Ethnomodeling is an important development in the various instructions of ethnomathematics programs, especially in interpreting various contexts into an ideal mathematical model. In other words, ethnomodeling is knowledge generated from various mathematical practices used in the culture of a community (Caldeira, 2007). The concept of ethnomodelling is seen as able to bridge the results of ethnomathematics research with academic mathematics. Ethnomodelling is one approach to the practical application of Ethnomathematics (Rosa \& Orey, 2011) which can be used to describe culture based on the modelling process (emic) with an academic mathematical representation (etic) and through a dialogical process (Rosa \& Orey, 2012). Based on this rationalism, ethnomodelling is expected to describe ethnomathematics researchers' results to be adopted into academic mathematics to realize multiculturalbased mathematics education.

Cultural integration in the existing mathematics curriculum is now vital based on the results of ethnomathematics studies that have been conducted or other comparable studies. When placed on a broader base of multicultural education literature, recent research shows that for those who teach mathematics in schools, the acceptance and understanding of cultural diversity is not an option but rather a necessity (Ogbu, 1992). Based on the ethnomathematics perspective, a culturally relevant mathematics curriculum focuses on the role of mathematics in a sociocultural context. It involves various ideas and concepts related to ethnomathematics and utilizes an ethnomathematics perspective to solve contextual problems (Orey \& Rosa, 2008). This perspective is an essential component of culturally relevant education through the contextualization of mathematics learning. Mathematical curriculum development like this is done by examining cultural congruence between the student and the school community.

The principle of cultural congruence can be implemented if the teacher has the knowledge and respect for various cultural and language traditions from students in the classroom (Zeichner, 1996). Therefore, they should build a clear understanding of their own ethnic and cultural identities in order to be able to understand and appreciate the ethnic and cultural identities of students to view mathematics as socially and culturally constructed scientific disciplines (Banks, 1991; Lee, 1999). Some experts have developed a culturally relevant pedagogical theory that studies the teaching and learning process in a critical paradigm and through explicit connections between students' culture and their school subjects (D'Ambrosio, 1990; Gay, 2000; Ladson-Billings \& Tate, 2016; Rosa \& Orey, 2003). 


\section{METHODOLOGY}

A realist ethnographic approach is used in this study through the use of exploratory research methods. Use the ethnographic approach to discover and describe the mind's organization (Spradley, 2016), as a social action that can transform a richer education (Lincoln \& Denzin, 2003). Ethnomathematics design adopts four elements consisting of generic questions, initial answers, critical constructs, and specific activities (Alangui, 2010) and is based on six dimensions of necessary universal mathematical activities, such as counting, discovering, measuring, designing, playing, and explaining (Bishop, 1988). Furthermore, emic, etic, and dialogical approaches are used in ethnomodelling research (Rosa \& Orey, 2012). The emic approach is used so that researchers get information from respondents about descriptions of mathematical activities that are used based on their culture. The approach is a technique in representing the academic mathematical process based on the researcher's perspective in academic mathematics. Meanwhile, the dialogical approach is a communication process that bridges if there is bias or a mismatch between emic and etic.

The research design used was realist ethnography. The research procedure was carried out with the arrangement of research subjects who were left to experience (no treatment), but the researcher acted as participant observation. The research subjects used in the study consisted of key informants, primary informants, and additional informants. The use of these three types of informants is for data validity purposes. The selection of research subjects is based on the following criteria.

1. Informants are community members who often interact with fellow members of the Cigugur Indigenous community.

2. Informants are community members who are active in various activities carried out by the Cigugur Indigenous community with frequent intensity.

3. Informants have a good understanding of the culture, customs, and habits of the Cigugur Adat community.

4. Informants have a willingness to become informants and have sufficient time to provide information whenever needed.

5. Informants can convey complete information either in their language (Sundanese) or Indonesian language (Bahasa).

Based on these criteria, the researcher chose five informants: the Head of the Cigugur Indigenous Community as the key informant, two traditional elders, or Ais Pangampih from the Cigugur Indigenous community as the primary informant, and two customary builders/carpenters of the Cigugur Adat community. As an additional informant. In practice, researchers collect information from these informants sequentially, starting from crucial informants, primary informants, and additional informants. Interviews conducted systematically based on the type of informant selected can guarantee the research data's validity because the clarification process can be done quickly to informants. The interview protocol for the three types of informants was carried out differently according to their respective characteristics.

Interviews conducted with key informants were initially conducted with an informal conversational interview. At this stage, the researcher asks background, behavioral, and demographic questions. This type of question is used to explore the types of technology and living equipment used by the majority of the community, the habits they often use, their environmental support, and their beliefs in the activities they do. In the next stage, the researcher then conducted an interview guide approach and standardized openended interviews in turn. The two interviews were conducted by giving knowledge questions and construction-forming questions to informants about how to construct buildings and the community's habits in calculating when they were about to build a house.

Meanwhile, interviews were conducted with primary informants and additional informants, which were conducted by alternating the guide approach and standardized open-ended interviews. Both types of interviews were conducted by providing experiential questions, behavioral questions, knowledge questions, constructional questions, and contrast questions. Contrast questions are conducted to ask respondents to distinguish one thing from another so that there is a cross-check of information that can ensure the validity and reliability of the research data. The questions posed to primary informants and additional informants focused on how to construct buildings, habits, and procedures used by the community in calculating when they were about to build a house. The five informants were interviewed three times with different time and place arrangements with the duration of the concession for each informant not less than 2 hours. The data collection was carried out directly by all researchers from August to September 2019 by using an audio recording device.

The data collection technique used was to adopt an ethnographic research design by conducting participant observation and in-depth interviews. Researchers carry out participant observation through direct participation in the situations or settings they observe while in-depth interviews are the primary technique used by qualitative researchers to find out respondents' ideas, opinions, and experiences (Fraenkel et al., 2011). Participant observations were made of residents of the Cigugur traditional community who had plans to build houses. Interviews were carried out in stages according to the 
predetermined types of informants. The research data were collected through observation and interviews to produce field notes, audio recordings, photos, and video recordings. Interviews aim to explore respondents' ideas, opinions, and experiences based on their thoughts and feelings. More specifically, the interviews conducted also aimed to compare or cross-check the results of the observations carried out.

This study's data analysis techniques consisted of content analysis techniques, triangulation, and pattern discovery. The content analysis technique presents valid data in detail about the research subjects' culture and habits carried out at the research location. Content analysis is a technique that can be used to study human behaviour indirectly through communication analysis (Cohen et al., 2013). Triangulation techniques can be used to determine the validity of an ethnographer's observations, which consists of checking what a person hears and sees by comparing information sources through cross-checking information sources. Simultaneously, pattern setting is a way to check ethnographic reliability towards revealing data consistency (Fraenkel et al., 2011). The triangulation technique used is the triangulation of data sources, the content analysis technique uses the symbol coding technique by interpreting/interpreting the data obtained, while the pattern discovery uses the creation of categories used in the analysis. Data analysis was carried out through data reduction, data display, data verification, and conclusion drawing. Based on these three data analysis techniques, researchers can guarantee the research data's validity and reliability.

\section{FINDINGS AND DISCUSSION}

The study results will describe the Cigugur indigenous community's habits to do calculations in determining good days for building houses based on the sum of the combination of the values attached to the hari, pasaran, and bulan. The values attached to the year, month, day, and market are called naktu or neptu (Suryaatamana et al., 1992). Naktu of each day is shown in Table 1.

Meanwhile, the time for each pasaran is shown in Table 2.

Each of hari has a certain pasaran and sequentially forms a cycle. In other words, one day (hari) matches precisely one the name of pasaran. So, it can be concluded that every day has a different pasaran name that can be called a cycle that is always repeated. The pair between the hari and pasaran cycle, shown in Figure 1.

Based on Figure 1, it can be understood that the pasaran repeats every five days while the days will repeat every one week (seven days), for example, ahad manis, senen pahing, salasa puhun, rebo wage, kamis kaliwon, jumaah manis, saptu pahing, etc. In mathematics, this cycle can be interpreted as a relation of two consecutive sets,
Table 1. The Name of Hari And Naktu

\begin{tabular}{lc}
\hline The name of hari/day & Value/Naktu \\
\hline Ahad (as of Sunday) & 5 \\
Senen (as of Monday) & 4 \\
Salasa (as of Tuesday) & 3 \\
Rabu (as of Wednesday) & 7 \\
Kemis (as of Thursday) & 8 \\
Jumaah (as of Friday) & 6 \\
Saptu (as of Saturday) & 9 \\
\hline
\end{tabular}

Table 2. The name of pasaran and value

\begin{tabular}{lc}
\hline The name of pasaran & Value/Naktu \\
\hline Manis & 5 \\
Pahing & 9 \\
Puhun & 7 \\
Wage & 4 \\
Kaliwon & 8 \\
\hline
\end{tabular}

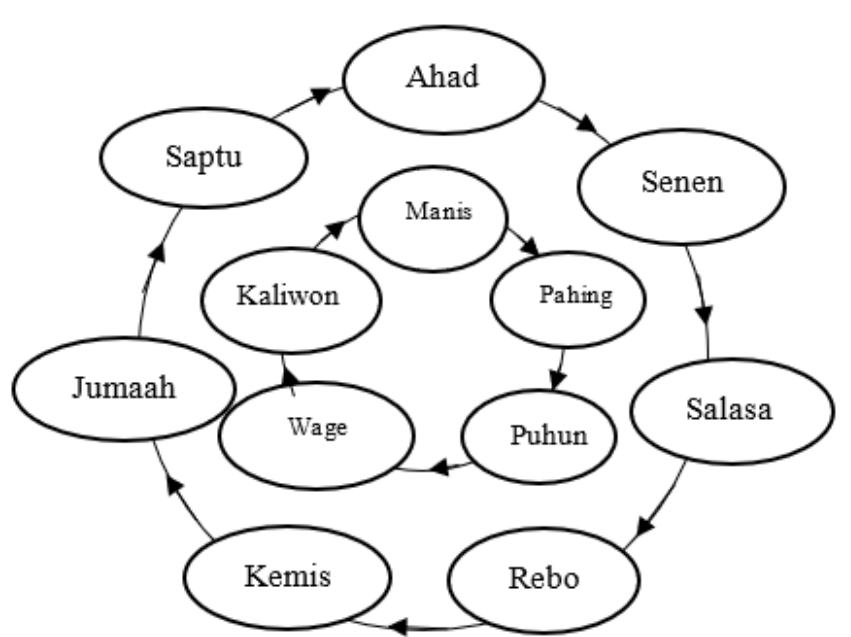

Figure 1. The cycle of hari and pasaran (Umbara et al., 2019)

which in one day (hari) has one pasaran that is paired in sequence. So that we can define, for example, $\mathrm{A}$ is a set of hari and B is a set of pasaran can be written $A=\{$ Ahad, Senen, Salasa, Rebo, Kemis, Jumaah, Saptu $\}$, and $B=\{$ Manis, Pahing, Puhun, Wage, Kaliwon\}. More formally, we have the definition of $\mathrm{R}$ as a relation from set $\mathrm{A}$ to set $\mathrm{B}$, as: $\{(x, y) \mid x \in A$ and $y \in B\}$. Next, determine the right day to start building houses in the Cigugur indigenous community using the following formula.

$$
\text { Det }=\frac{n h+n p}{5}
$$

Explanation:

Det : Determination of Good Day to Build a House

$\mathrm{Nh}$ : Naktu Hari/the value of hari

$\mathrm{Np}$ : Naktu Pasaran/the value of pasaran

The formula can be operated with a fixed standard of naktu attached to hari and pasaran. The formula is operated to determine the residual value of the division. The division's remaining value is then used as a measure to determine the criteria for good days. The criteria used to determine good days are based on Table 3. 
Table 3. Criteria for Results of Determination of Good Days

\begin{tabular}{lcc}
\hline The criteria of hari & Remaining of Division & The meaning \\
\hline Pati & 0 & Mati (the die) \\
Sri & 1 & Dewi padi (Prosperity) \\
Lungguh & 2 & Kedudukan (Position/Level) \\
Dunya & 3 & Dunia (Wealth) \\
Lara & 4 & Sengsara (misery) \\
\hline
\end{tabular}

Of the five criteria, the community's habit of using criteria sri, lungguh dan dunya. Nevertheless, the criteria for dunya are usually used as the best day to start building a house. Following the previous explanation, the criteria used to determine good days in building a house consist of 5 criteria. Therefore, the concept of modulo. Since each calculation is divided by 5 , then modulo 5. is obtained. In the world of mathematics, this phenomenon is known as congruence, which can be defined as integers $a$ and integers $b$ are said to be congruent in modulo $\mathrm{n}$ if and only if they give the remainder for the same when divided where $\mathrm{n}$, where, $b, n \in \mathbb{Z}$. Symbolically stated with $a \equiv b(\bmod n)$. So, the mathematical model can be formulated as follows.

$$
a \equiv c(\bmod 5) \text { or } a=5 q+c
$$

Where $a$ is the determinant of the day criteria and $c$ is the remainder of the division. For example $b$ to determine the type of day that can be used to build a house, then:

1. For those with no remaining division/0 (Pati), then:

$b \equiv 0(\bmod 5)$ or $b=5 q+0$

The criteria of pati meet the equation :

$b=5 q$

If $q=1$, then $b=5(1) \rightarrow b=5$

If $q=2$, then $b=5(2) \rightarrow b=10$

If $q=3$, then $b=5(3) \rightarrow b=15$

2. For the remaining division 1 (Sri), then:

$b \equiv 1(\bmod 5)$ or $b=5 q+1$

The criteria of sri meet the equation:

$b=5 q+1$

If $q=1$, then $b=5(1)+1 \rightarrow b=6$

If $q=2$, then $b=5(2)+1 \rightarrow b=11$

If $q=3$, then $b=5(3)+1 \rightarrow b=16$

3. For the remaining division 2 (Lungguh), then: $b \equiv 2(\bmod 5)$ or $b=5 q+2$

The criteria of lungguh meet the equation:

$b=5 q+2$

If $q=1$, then $b=5(1)+2 \rightarrow b=7$

If $q=2$, then $b=5(2)+2 \rightarrow b=12$

If $q=3$, then $b=5(3)+2 \rightarrow b=17$

4. For the remaining division 3 (Dunya), then:

$b \equiv 3(\bmod 5)$ or $b=5 q+3$
The criteria of dunya meet the equation:

$$
\begin{aligned}
& b=5 q+3 \\
& \text { If } q=1, \text { then } b=5(1)+3 \rightarrow b=8 \\
& \text { If } q=2, \text { then } b=5(2)+3 \rightarrow b=13 \\
& \text { If } q=3 \text {, then } b=5(3)+3 \rightarrow b=18
\end{aligned}
$$

5. For the remaining division 4 (Lara), then:

$$
b \equiv 4(\bmod 5) \text { or } b=5 q+4
$$

The criteria of lara meet the equation:

$$
\begin{aligned}
& b=5 q+4 \\
& \text { If } q=1, \text { then } b=5(1)+4 \rightarrow b=9 \\
& \text { If } q=2, \text { then } b=5(2)+4 \rightarrow b=14 \\
& \text { If } q=3 \text {, then } b=5(3)+4 \rightarrow b=19
\end{aligned}
$$

The composition of naktu attached to hari and pasaran is a symbol that can produce a standard configuration. This configuration can quickly determine the best time to build a house. For that purpose, a matrix can clarify the relationship between the two in determining the day criteria based on predetermined criteria. For example, a resident of the Cigugur indigenous community who was born on the date has the goal of building a house in September 2020. The first day of September 2020 is Tuesday (Salasa kaliwon), the combination of days is Wednesday: Wednesday (rebo manis), Thursday (kemis pahing), Friday (jumaah puhun), Saturday (saptu wage), Sunday (ahad kaliwon), etc. Following the combination of days and markets in one month, the good days that can be used to start building a house with the dunya category are the days: jumaah puhun (Friday, September 4, 2020), ahad kaliwon (Sunday, September 6, 2020), saptu wage (Saturday, September 5, 2020), kemis manis (Thursday, September 17, 2020), salasa manis (Tuesday, September 22, 2020), and senen pahing (Monday, September 28, 2020).

Based on the calculation results, the percentage of day categories in one day and the market are shown in Figure 2.

Based on the habits of the people who use the day with the Sri criteria, the Lungguh criteria and the Dunya criteria can be an option with a percentage of $65.72 \%$. Thus, the criteria for good days become the most dominant choice among other days, which are perceived as bad days or avoided in carrying out housing construction. Based on a study of how the Cigugur indigenous community determined the excellent day to start building a house, they can understand that they use the principle of counting numbers, mostly besides 


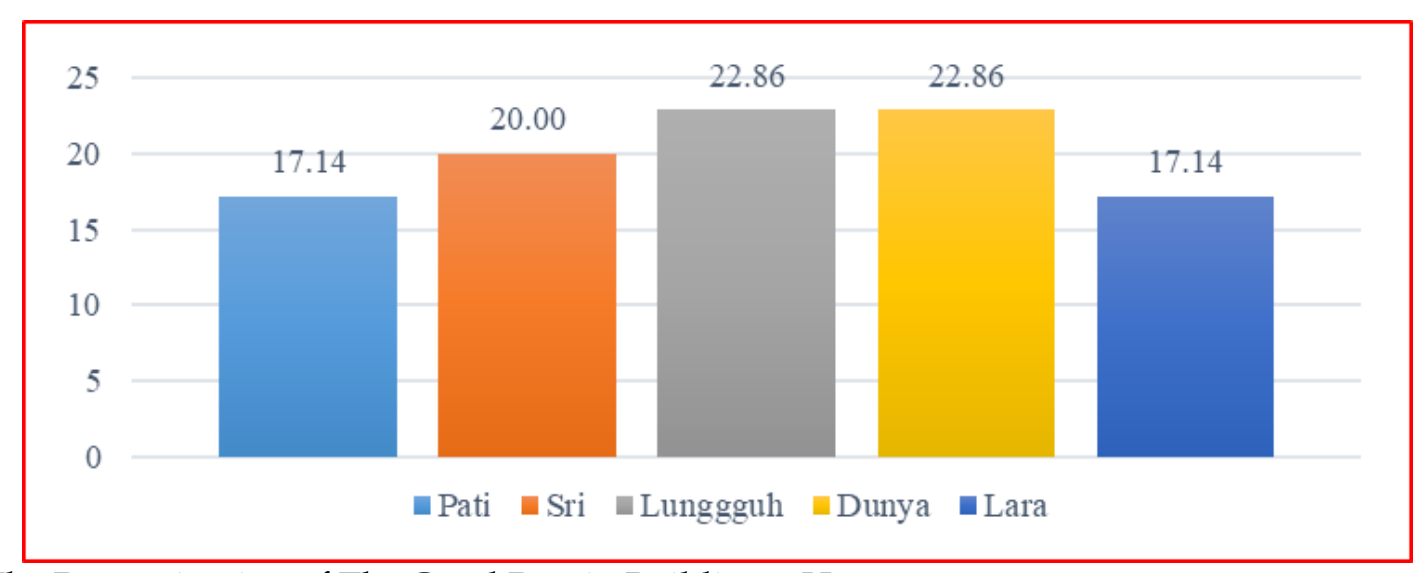

Figure 2. The Determination of The Good Day in Building a House

division and comparison operations. The addition and division concept can be known based on the formula that has been explained before, where people do the sum of the time of day, and the time of the market, then they do the distribution to get the remaining figures from the division. Meanwhile, the comparison concept is used to compare the remainder of the division results with predetermined criteria. In other words, the Cigugur indigenous people use the concept of evaluation to determine good days in building a house, where they take measurements and judge days based on standard measurements. It is under the dimensions of necessary universal mathematical activities, such as counting, placing, and explaining.

The ability to count is one of the community's essential abilities, mostly functioning to support other necessary mathematical abilities such as grouping, measuring, designing, and explaining. So it has a fundamental position in the mathematical activities of the society. Even though it is often classified as the most straightforward activity, it will not be easy to have other, more complex abilities without numeracy skills. Counting is closely related to symbols or symbols. There are various symbols of different numbers as bright as this, such as ancient Egypt, Babylonia, ancient Greece, China, Japan-China, Arabic-Hindu, Roman, and Mayan tribes. The first civilizations that were believed to use symbols were ancient Egyptian and Babylonian civilizations (Fathani, 2009). The use of number symbols in Indonesia and most other countries (including western mathematics / academic mathematics) adopts the Arabic-Hindu number system.

Number symbols are spirits in the development and progress of mathematics. It would not be easy to imagine if the numbers did not exist. The primary function of numbers in mathematical concepts is that they can be used for enumeration and measurement. Numbers are abstract ideas but can provide information that can be understood in full of community communication. The symbol of numbers then produces ideas, procedures, and other mathematical activities that are more complex. Besides, because the use of symbol numbers in enumeration activities is a routine activity in daily life, it contains unique and exclusive patterns. The uniqueness and exclusivity are because the symbols are used to make predictions or predictions of an event.

The calculation of good days is closely related to public trust so that the implementation is not binding or flexible. The truth of predictions/predictions depends on one's belief in the hope that it will not negatively impact the activities or work to be carried out (Suryaatamana et al., 1992). However, most people believe and carry out the results of these calculations. Once the Sundanese believe in the matter of calculation, to the point of defeating rational considerations, they hope that they will get the results that they want and provide happiness physically and mentally through these calculations (Suryaatamana et al., 1992). Based on cultural reviews, the calculation of good days can be classified into the elements of knowledge systems and religious systems (beliefs) that fulfil culture as a system of ideas and activity systems. The form of culture as a system of ideas is very abstract, found in individuals' minds adherents of culture, and can only be felt in everyday life. In contrast, as a system of activities, culture is reflected in social activities or activities patterned continuously by individuals in society (Koentjaraningrat, 1985).

On the other hand, the results of studies support the view that ethnomathematics is a mathematical practice carried out by cultural groups ( $\mathrm{D}^{\prime}$ Ambrosio, 1989) and is the antithesis of the assumption that mathematics is only produced by mathematicians (Borba, 1992). Mathematical ideas and practices carried out by the Cigugur indigenous community in determining good days belong to inclusive enumeration. An inclusive enumeration is an enumeration that is usually done by the community to count the days in a calendar. Enumeration activities are activities that are classified as old in the practice of mathematics. Allegedly since 50,000 years ago, humans have been enumerating. It is proven, based on archaeological evidence (Eves \& Eves, 1964). All human activities are realized or not, carried out based on appropriate calculations by their residence's 
natural conditions (Maryati \& Prahmana, 2018). Calculation activities are fundamental activities carried out by each individual in daily activities for a particular purpose, both in personal life and in the life of society, nation, and state.

The study results showed that the mathematical concept was inseparable from people's daily lives, especially in carrying out calculation activities. In this case, mathematics is knowledge inherent in life activities (Nurhasanah et al., 2017), so it is believed that the conceptualization of mathematics and culture are two concepts integrated with human life that are difficult to separate from one another (Umbara et al., 2019). Thus, it is believed that mathematics has social and cultural interests (Noyes, 2007), so that the role of mathematics as a solution to solving problems and becoming a tool in meeting the needs of individuals and society in the context of social activities and relationships becomes indisputable (Umbara \& Suryadi, 2019), especially in investigating technology and scientific activities in human development (Aikpitanyi \& Eraikhuemen, 2017).

As the final statements, ethnomathematics can be seen as scientific studies that bridge the interaction between multicultural practices and mathematical conceptuality. Ethnomathematics is a basic framework that can strengthen mathematics education development's critical nature in a reciprocal way (Baba \& Iwasaki, 2001). The capacity of ethnomathematics lies in its ability to provide an excellent way to express mathematical concepts that grow and develop naturally in the lives of certain people according to their daily needs (Umbara et al., 2019) by utilizing mathematical practices that are commonly found in the sociocultural environment of the students themselves (Matang, 2002). On the other hand, mathematics has been recognized as the basis of intellectual instruments for science and technology, especially for validating social, political, and academic matters through data manipulation (Abbas, 2000).

Based on the ethnomodelling approach, it is known that the concept used by the Cigugur traditional community is relevant to the concept of integer emptiness. Emically (the cultural group members' interpretation of their own culture), the Cigugur indigenous community uses a standard formula to determine a good day in building a house. They use the symbolization of time every day and the market, which is followed by placing numbers according to standard rules, calculating each value to produce the remainder of the division, and explaining the types of good days according to predetermined standard criteria. The numbers are placed according to the standard rules by the predetermined time and number operation formulations. Based on the ethical approach, the researcher assesses some of the Cigugur traditional community's mathematical concepts by the concepts of enumeration, integer operations, sets, relations, congruence, and modulo.

Meanwhile, based on emic and etic communication (referred to as the dialogical/glocal approach), the standard formula for determining good days can be made mathematical modelling. The mathematical modelling that is formed is relevant to the concept of integer emptiness. Let $a, b$, and $n$ be positive integers, then the number a is congruent to $b$ modulo $n$ if and only if $a-b=k n$, for a $\mathrm{k}$ integer. If the numbers $a$ and $b$ are congruent in modulo $n$ denoted by $a \equiv b(\bmod n)$. $a$ and $b$ are called congruent modulo $\mathrm{n}$, denoted by $a \equiv b$. For example, $a$ positive integer is congruent to $b$ with modulo $n$ if and only if $a-b=k n$ for an integer $k$.

For the Cigugur indigenous community, mathematical modelling based on the concept of modulo and congruence can make it easier to determine the criteria for the day of house construction. Meanwhile, for learning mathematics in schools, the research results can be used to teach teachers. The concept of enumeration, integer operation, set, relation, congruence, and modulo can be taught through mechanistic and empiric approaches. The mechanistic approach is traditional and is based on what is known from one's own experience. A mechanistic approach can make students considered machines because there is no mathematical process in it. Thus, the empirical approach can collaborate in learning to complete it because the empiric approach is carried out with a horizontal mathematical process, where mathematical concepts are not taught directly. It is hoped that students can find out independently through social contexts in determining good days.

In this regard, merely the research results can revitalize school mathematics teaching materials, which usually tend to be done using a structuralistic approach. The ethnomodelling approach used in this research can provide a new perspective on learning ethnomathematics. Ethnomodelling, as a methodology in ethnomathematics learning, plays an essential role in designing pedagogical tools and actions as a role model for the development of mathematics education teaching materials. As a form of revitalizing the contemporary mathematics learning process, teachers can get used to starting mathematics learning by using calculation activities used by the Cigugur indigenous community to teach the concepts of enumeration, integer operations, sets, relations, congruence, and modulo. Similar processes have been carried out by other researchers who used the results of ethnomodelling studies to study geometric properties and introduced the concept of rectangles, triangles, and circles based on the traditional way of making circles or rectangles in Mozambique (Soares, 2009).

Based on this process, ethnomodelling can be claimed as a suitable approach to making ethnomathematics research useful for research subjects (a community) and 
revitalizing the mathematics learning process in schools. Ethomodelling as a pedagogical tool (Rosa \& Orey, 2010), pedagogical actions (Rosa \& Orey, 2011), and methodology in the study of Ethnomathematics (Rosa \& Orey, 2013a), has a central role in bridging and translating cultural aspects in mathematics and mathematical modelling so that it can be used in multicultural-based mathematics education as teaching material for students. The ethnomodelling study conducted provided a basis for researchers in translating cultural aspects of phenomena into academic mathematics through mathematical modelling.

The ethnomodelling study provides strong evidence of patterns of interaction between mathematics and the world of mathematics education that do not entirely overlap when communication is built using mathematical modelling (Burkhardt, 2006) to anticipate conceptual blur (Lesh \& Fennewald, 2013). However, researchers have not yet agreed on the modelling process and how to make mathematical modelling concepts (Zawojewski, 2013). However, ethnomodelling provides excellent hope that plays a role in creating and implementing didactic situations in shaping pedagogical tools in learning mathematics by promoting cultural aspects. Etnomodelling as an approach plays a role in solving problems and understanding alternative mathematical systems (Rosa \& Orey, 2016) and helps students understand the vital role of mathematics in society (de Loiola Araújo, 2010).

Ethnomathematics study, through the use of the ethnomodelling approach, can produce more complete study results than just exploring mathematical forms based on cultural aspects. Ethnomodelling can continue and improve ethnomathematics research's performance, especially on cultural aspects related to aspects of mathematical modelling through a glogical/dialogical approach that provides communication space between etic and emics. It becomes a role model in elevating mathematical modelling based on the cultural aspects of school mathematics. It is closely related to modelling from learning to achieve mathematical construction knowledge (Ikeda, 2013). It is based on the capacity to model and find solutions to situations that can serve individuals in everyday life (Cai et al., 2014) to build new knowledge or reconstruct the knowledge they have acquired (Van Den Heuvel-Panhuizen, 2003).

The didactic situation developed by educators based on ethnomodelling studies is expected to be a solution in developing contemporary teaching materials to reform long-term mathematics learning because it cannot be denied that the practice of mathematical modelling is often felt to be very difficult for students. This difficulty is due to the modelling task's cognitive demands (Blum \& Ferri, 2009), related to other mathematical competencies such as reading and communicating, designing, reasoning, and implementing the problemsolving strategies (Niss, 2003).
In the future, it will become commonplace if a teacher bases the learning process on aspects of the culture that they encounter around them as a tool to create a didactic situation. To erode the difficulties and even phobias felt by most students in learning mathematics. Ethnomathematics can be used to increase learning motivation, mathematics achievement, revolutionize students' social mobility abilities, increase students' sense of belonging to their immediate environment, and their cultural values and traditions (Fouze \& Amit, 2018). On the other hand, this study's results prove that ethnomathematics can maximize educators' potential to reform long-term mathematics learning because it cannot be denied that the practice of mathematical modelling is often felt very difficult for students. Based on the educator's perspective, the ethnomathematics approach can revolutionize their thinking and perspectives (Fouze \& Amit, 2018), so it is recommended that teachers can be helped to develop an awareness of the ethnomathematics approach, especially in making pedagogical approaches that are more flexible and student-centered (Sunzuma \& Maharaj, 2019).

\section{CONCLUSION}

Mathematical ideas and practices owned and used from generation to generation by the community in the Cigugur indigenous community, especially in determining the right day when they start housing construction, can be viewed from various aspects. The first aspect is based on cultural aspects. The practice is classified as a local genius that meets the holistic principle in understanding cultural elements. The holistic concept can be understood as the relationship between one element and other elements in a cultural unity, including the knowledge system and the religious system (belief). Based on this holistic concept, the growth of trust in a day considered acceptable is related to people's knowledge and ability to use mathematical ideas and practices. Based on the ethnomathematics program, ideas, and practices of the Cigugur indigenous community mathematics, the second aspect can be classified into several fundamental mathematics dimensions. The third aspect is based on ethnomodelling studies. Mathematical models can be elaborated and constructed comprehensively. The resulting mathematical model can help determine five-day criteria in starting housing construction in the Cigugur indigenous community to enable them to judge the day criteria through a faster process.

Ethnomathematics and ethnomodelling studies in this study can bridge communication between cultural aspects and traditional mathematical concepts. The use can bridge the obscurity of the mathematical concepts used by indigenous communities. The hereditary habits in calculation activities can be used in school mathematics or academic mathematics. Therefore, 
simultaneous learning of mathematics based on cultural aspects can be a solution for introducing culture and learning mathematics in an integrated way. So learning mathematics has several functions, including as a process of forming the character of love for the surrounding culture, a form of cultural preservation, awareness of the role and function of mathematics in the social environment, and social empowerment through mathematics to build critical thinking in the life of the nation and state.

\section{ACKNOWLEDGEMENTS}

The authors would like to express appreciation and gratitude to the Ministry of Education and Culture and the Ministry of Research and Technology/National Agency for Research and Innovation as scholarship and grants and all parties who have a significant impact on the success and completion of this research. The authors realize that this article is far from perfect; therefore, constructive criticism and suggestions are needed to achieve this perfection. Hopefully, this research is useful for readers.

\section{REFERENCES}

Abbas, S. A. (2000). Ethnomathematics and teaching of mathematics in primary schools: a new perspective. Kano Studies, 1(1), 135-144.

Abdullah, A. S. (2017). Ethnomathematics in perspective of sundanese culture. Journal on Mathematics Education, 8(1), 1-16. https://doi.org/10.22342/ jme.8.1.3877.1-15

Aikpitanyi, L. A., \& Eraikhuemen, L. (2017). Mathematics teachers' use of ethnomathematics approach in mathematics teaching in edo state. Journal of Education and Practice, 8(4), 34-38.

Alangui, W. V. (2010). Stone Walls and Water Flows: Interrogating Cultural Practice and Mathematics. ResearchSpace@Auckland.

Ascher, M. (1991). Ethnomathematics: A Multicultural View of Mathematical Ideas. Cole Publishing Company, California.

Ascher, M., \& Ascher, R. (1986). Ethnomathematics. History of Science, 24(2), 125-144. https:/ / doi.org/10.1177/007327538602400202

Baba, T., \& Iwasaki, H. (2001). Intersection of Critical Mathematics Education and Ethnomathematics. Journal of Science Education in Japan, 25(3), 191-199.

Banks, J. A. (1991). A curriculum for empowerment, action, and change. Empowerment through Multicultural Education, 125-141.

Barton, B. (1996). Ethnomathematics: Exploring cultural diversity in mathematics. ResearchSpace@ Auckland.
Barton, B., \& Frank, R. (2013). Mathematical ideas and indigenous languages. In Sociocultural Research on Mathematics Education (pp. 163-178). Routledge.

Bishop, A. J. (1988). Mathematics education in its cultural context. Educational Studies in Mathematics, 19(2), 179-191. https:/ / doi.org/10.1007/BF00751231

Bishop, A. J. (1991). Mathematical Enculturation: A Cultural Perspective on Mathematics Education (Vol. 6). Springer Science \& Business Media.

Bishop, A. J. (1999). Mathematics teaching and values education - an intersection in need of research. ZDM, 31(1), 1-4. https://doi.org/10.1007/s11858999-0001-2

Blum, W., \& Ferri, R. B. (2009). Mathematical modelling: Can it be taught and learnt? Journal of Mathematical Modelling and Application, 1(1), 45-58.

Bonotto, C. (2007). How to replace word problems with activities of realistic mathematical modelling. In Modelling and Applications in Mathematics Education (pp. 185-192). Springer. https://doi.org/10.1007/ 978-0-387-29822-1_18

Borba, M. de C. (1987). Um Estudo de Etnomatemática: sua incorporação na elaboração de uma proposta pedagógica para o "núcleo-escola" da favela da vila nogueira-São Quirino [An Ethnomathematics Study: its incorporation in the elaboration of a pedagogical proposal for the "coreschool" of the favela of the village nogueira-São Quirino] (Master's Dissertation, Mathematics Education). UNESP - Rio Claro.

Borba, M. de C. (1990). Ethnomathematics and Education. For the Learning of Mathematics, 10, 1.

Borba, M. de C. (1992). Teaching mathematics: Ethnomathematics, the voice of sociocultural groups. The Clearing House, 65(3), 134-135. https: / / doi.org/10.1080/00098655.1992.10114182

Burkhardt, H. (2006). Modelling in Mathematics Classrooms: reflections on past developments and the future. ZDM, 38(2), 178-195. https: / / doi.org/10.1007/BF02655888

Cai, J., Cirillo, M., Pelesko, J. A., Borromeo Ferri, R., Borba, M., Geiger, V., Stillman, G., English, L. D., Wake, G., Kaiser, G., \& Kwon, O. N. (2014). Mathematical modeling in school education: Mathematical, cognitive, curricular, instructional and teacher education perspectives. Proceedings of the Joint Meeting of PME 38 and PME-NA 36, 1, 145172.

Caldeira, A. D. (2007). Etnomodelagem e suas relações com a educação matemática na infância [Ethnomodeling and its relationship with mathematics education in childhood]. Modelagem Matemática $\mathrm{Na}$ Educação Matemática Brasileira: Pesquisas e Práticas Educacionais. Recife: SBEM Mathematical Modeling in Brazilian Mathematical 
Education: Research and Educational Practices. Recife: SBEM, 81-97.

Cimen, O. A. (2014). Discussing ethnomathematics: Is mathematics culturally dependent? Procedia-Social and Behavioral Sciences, 152, 523-528. https:/ / doi.org/10.1016/j.sbspro.2014.09.215

Cohen, L., Manion, L., \& Morrison, K. (2013). Research Methods in Education. Routledge. https:/ / doi.org/10.4324/9780203720967

D'Ambrosio, U. (1985). Ethnomathematics and its place in the history and pedagogy of mathematics. For the Learning of Mathematics, 5(1), 44-48.

D'Ambrosio, U. (1989). On ethnomathematics. Philosophia Mathematica, 2(1), 3-14. https:/ / doi.org/10.1093/philmat/s2-4.1.3

D’Ambrosio, U. (1990). Etnomatemática (Ethnomathematics). São Paulo, SP, Brazil: Editora Ática.

D'ambrosio, U. (1995). Multiculturalism and mathematics education. International Journal of Mathematical Education in Science and Technology, 26(3), 337-346. https://doi.org/10.1080/0020739 950260304

D'Ambrosio, U. (1997). Ethnomathematics and its place in the history and pedagogy of mathematics. Ethnomathematics: Challenging Eurocentrism in Mathematics Education, 13-24.

D'ambrosio, U. (2016). Etnomatemática-elo Entre as Tradições e A Modernidade [Ethnomathematics-link between Traditions and Modernity]. Autêntica.

de Loiola Araújo, J. (2010). Brazilian research on modelling in mathematics education. ZDM, 42(3-4), 337-348. https://doi.org/10.1007/s11858-0100238-9

Domite, M. do C. S. (2004). Notes on teacher education: an ethnomathematical perspective. In F. Favilli (Ed.), Ethnomathematics and Mathematics Education: Proceedings of the 10th International Congress of Mathematics Education, Copenhagen (pp. 17-28). PISA: Tipografia Editrice Pisana.

Eglash, R. (1997). When math worlds collide: Intention and invention in ethnomathematics. Science, Technology, \& Human Values, 22(1), 79-97. https://doi.org/10.1177/016224399702200104

Ekajati, E. S. (1995). Kebudayaan Sunda: Suatu Pendekatan Sejarah (Vol. 1). Pustaka Jaya.

Ernest, P. (1991). The Philosophy of Mathematics Education. Taylor \& Francis Group.

Eves, H., \& Eves, J. H. (1964). An Introduction to the History of Mathematics (Vol. 6). New York: Holt, Rinehart and Winston.

Fathani, A. H. (2009). Matematika Hakikat dan Logika. Yogyakarta: Ar-Ruzz Media.
Fouze, A. Q., \& Amit, M. (2017). On the importance of an ethnomathematical curriculum in mathematics education. EURASIA Journal of Mathematics, Science and Technology Education, 14(2), 561-567. https:/ / doi.org/10.12973/ ejmste/76956

Fouze, A. Q., \& Amit, M. (2018). Development of mathematical thinking through integration of ethnomathematics folklore game in math instruction. EURASIA Journal of Mathematics, Science and Technology Education, 14(2), 617-630. https:/ / doi.org/10.12973/ ejmste/80626

Fraenkel, J. R., Wallen, N. E., \& Hyun, H. H. (2011). How to Design and Evaluate Research in Education. New York: McGraw-Hill Humanities / Social Sciences / Languages.

Francois, K., \& Van Kerkhove, B. (2010). Ethnomathematics and the philosophy of mathematics (education). In B. Lowe, \& Y. Muller (Eds.), PhiMSAMP. Philosophy of Mathematics: Sociological aspects and mathematical practice (pp. 121154). London: College Publications.

Gagne, R. M. (1983). Some issue in psychology of mathematics instruction. Journal for Research in Mathematics Education, 14(1), 7-18. https:// doi.org/10.2307/748793

Galperin, P. Y., \& Georgiev, L. S. (1969). The formation of elementary mathematical notions. In J. Kilpatrick, \& I. Wirszup (Eds.), Soviet Studies in the Psychology of Learning and Teaching Mathematics. Vol. I: The learning of Mathematical Concepts (pp. 189-216). University of Chicago Press.

Gay, G. (2000). Culturally Responsive Teaching: Theory, Practice and Research. New York: Teachers College Press.

Gay, J., \& Cole, M. (1967). The New Mathematics in an Old Culture: A Study of Learning among the Kpelle of Liberia. Holt, Renehart \& Winston.

Gerdes, P. (1994). Reflections on ethnomathematics. For the Learning of Mathematics, 14(2), 19-22.

Gerdes, P. (1996). Ethnomathematics and mathematics education. In A. J. Bishop, M. A. (Ken) Clements, K. Clements, C. Keitel, J. Kilpatrick, \& C. Laborde (Eds.), International handbook of mathematics education (pp. 909-943). Kluwer Academic Publishers. https://doi.org/10.1007/978-94-0091465-0_28

Gerdes, P. (1998). On culture and mathematics teacher education. Journal of Mathematics Teacher Education, 1(1), 33-53. https://doi.org/10.1023/A:1009955 031429

Gerdes, P. (2001). Ethnomathematics as a new research field, illustrated by studies of mathematical ideas in African history. Science and Cultural Diversity: Filing a Gap in the History of Sciences. Cuadernos de Quipu, 5, 10-34. https:/ / doi.org/10.1.1.551.2369 
Hammond, T. (2000). Ethnomathematics: Concept Definition and Research Perspectives. New York: Columbia University.

Ikeda, T. (2013). Pedagogical reflections on the role of modelling in mathematics instruction. In Teaching Mathematical Modelling: Connecting to Research and Practice (pp. 255-275). Springer. https: / /doi.org/10.1007/978-94-007-6540-5_22

Katamba, F. (1993). Morphology. The Macmillan Press Ltd. https:/ / doi.org/10.1007/978-1-349-22851-5

Knijnik, G. (1993). Ethno-mathematical approach in mathematical education: a matter of political power. For the Learning of Mathematics, 13(2), 23-25.

Knijnik, G. (2007). Brazilian peasant mathematics, school mathematics and adult education. Adults Learning Mathematics, 2(2), 54-62.

Koentjaraningrat, K. (1985). Kebudayaan, Mentalitas dan Pembangunan [Culture, Mentality and Development]. Jakarta: Gramedia. PT. Gramedia.

Ladson-Billings, G., \& Tate, W. F. (2016). Toward a critical race theory of education. In Critical race theory in education (pp. 10-31). Routledge. https:/ / doi.org/10.4324/9781315709796-2

Lee, O. (1999). Science knowledge, world views, and information sources in social and cultural contexts: Making sense after a natural disaster. American Educational Research Journal, 36(2), 187-219. https://doi.org/10.3102/00028312036002187

Lesh, R., \& Fennewald, T. (2013). Introduction to Part I modeling: What is it? Why do it? In Modeling students' mathematical modeling competencies (pp. 510). Springer. https:/ / doi.org/10.1007/978-94-0076271-8_2

Lesser, L. M. (2006). Book of numbers: Exploring Jewish mathematics and culture at a Jewish high school. Journal of Mathematics and Culture, 1(1), 8-31.

Lincoln, Y. S., \& Denzin, N. K. (2003). Turning points in qualitative research: Tying knots in a handkerchief. Rowman Altamira.

Maryati, M., \& Prahmana, R. C. I. (2018). Ethnomathematics: exploring the activities of designing kebaya kartini. MaPan: Jurnal Matematika Dan Pembelajaran, 6(1), 11-19. https://doi.org/ 10.24252/mapan.2018v6n1a2

Matang, R. (2002). The role of ethnomathematics in mathematics education in Papua New Guinea: Implications for mathematics curriculum. Journal of Educational Studies, 24(1), 27-37.

Millroy, W. L. (1992). An ethnographic study of the mathematical ideas of a group of carpenters. Journal for Research in Mathematics Education. Monograph, i-210. https:/ / doi.org/10.2307/749904

Muhtadi, D., Sukirwan, Warsito, \& Prahmana, R. C. I. (2017). Sundanese ethnomathematics:
Mathematical activities in estimating, measuring, and making patterns. Journal on Mathematics Education, 8(2), 185-198. https:/ / doi.org/10.22342/ jme.8.2.4055.185-198

Niss, M. (2003). Mathematical competencies and the learning of mathematics: The Danish KOM project. 3rd Mediterranean Conference on Mathematical Education, 115-124.

Noyes, A. (2007). Rethinking School Mathematics (Vol. 1). PCP Sage Publications Company.

Nurhasanah, F., Kusumah, Y. S., \& Sabandar, J. (2017). Concept of triangle: Examples of mathematical abstraction in two different contexts. International Journal on Emerging Mathematics Education, 1(1), 5370. https://doi.org/10.12928/ijeme.v1i1.5782

Ogbu, J. U. (1992). Understanding cultural diversity and learning. Educational Researcher, 21(8), 5-14. https://doi.org/10.3102/0013189X021008005

Ojose, B. (2011). Mathematics Literacy : Are We Able To Put The Mathematics We Learn Into Everyday Use? Journal of Mathematics Education., 4(1), 89-100. http:/ / educationforatoz.com/images/8.Bobby_Oj ose_--_Mathematics_Literacy_Are_We_Able_To_ Put_The_Mathematics_We_Learn_Into_Everyday_ Use.pdf

Orey, D. C., \& Rosa, M. (2006). Ethnomathematics: Cultural assertions and challenges towards pedagogical action. The Journal of Mathematics and Culture, 1(1), 57-78.

Orey, D. C., \& Rosa, M. (2008). Ethnomathematics and cultural representations: teaching in highly diverse contexts.

Palhares, P. (2010). Studying artifacts in order to find out people's ways of thinking mathematically. Pme Conference Proceedings, 1, 323-327.

Powell, A. B., \& Frankenstein, M. (1997). Ethnomathematics: Challenging Eurocentrism in mathematics education. State University of New York Press Albany, NY.

Presmeg, N. C. (1998). Ethnomathematics in teacher education. Journal of Mathematics Teacher Education, 1(3), 317-339. https://doi.org/10.1023/A:100994 6219294

Rosa, M., \& Orey, D. C. (2003). Vinho e queijo: etnomatemática e modelagem! Bolema-Boletim de Educação Matemática, 16(20), 1-16.

Rosa, M., \& Orey, D. C. (2005). Las races históricas del programa etnomatemáticas. Revista Latinoamericana de Investigación En Matemática Educativa, RELIME, 8(3), 363-377.

Rosa, M., \& Orey, D. C. (2010). Ethnomodeling as a pedagogical tool for the ethnomathematics program. Revista Latinoamericana de Etnomatemática, 3(2), 14-23. 
Rosa, M., \& Orey, D. C. (2011). Ethnomodeling: a pedagogical action for uncovering ethnomathematical practices. Journal of Mathematical Modelling and Application, 1(3), 58-67.

Rosa, M., \& Orey, D. C. (2012). The field of research in ethnomodeling: emic, ethical and dialectical approaches. Educação e Pesquisa, 38(4), 865-879. https:/ / doi.org/10.1590/S1517-970220120004 00006

Rosa, M., \& Orey, D. C. (2013a). Ethnomodelling as a methodology for ethnomathematics. In Teaching mathematical modelling: connecting to research and practice (pp. 77-88). Springer. https: / / doi.org/10.1007/978-94-007-6540-5_6

Rosa, M., \& Orey, D. C. (2013b). The mathematics of the curves on the wall of the Colégio Arquidiocesano and its mathematical models: a case for ethnomodeling. Journal of Mathematical Modelling and Application, 1(8), 42-62.

Rosa, M., \& Orey, D. C. (2016). State of the art in Ethnomathematics. In Current and future perspectives of ethnomathematics as a program (pp. 11-37). Springer. https://doi.org/10.1007/978-3-31930120-4_3

Rubio, J. S. (2016). The ethnomathematics of the Kabihug Tribe in Jose Panganiban, Camarines Norte, Philippines. Malaysian Journal of Mathematical Sciences, 10, 211-231.

Schoenfeld, A. H. (1989). Teaching mathematical thinking and problem solving. In L. B. Resnick, \& B. L. Klopfer (Eds.), Toward the Thinking Curriculum: Current Cognitive Research (pp. 83-103). (1989 Yearbook of the American Society for Curriculum Development). Washington, DC: ASCD.

Soares, D. B. (2009). The incorporation of the geometry involved in the traditional house building in mathematics education in Mozambique: the cases of zambezia and sofala provinces.

Solaiman, N. P., \& Manalundong, M. Q. (2017). The mathematical ideas involved in Maranao Weaving. Journal of Social Sciences (COESERJ-JSS), 6, 610-617. https:/ / doi.org/10.25255/jss.2017.6.3.610.617

Spradley, J. P. (2016). The Ethnographic Interview. Waveland Press.

Sunzuma, G., \& Maharaj, A. (2019). Teacher-related Challenges Affecting the Integration of Ethnomathematics Approaches into the Teaching of Geometry. Eurasia Journal of Mathematics, Science and Technology Education, 15(9), em1744. https: / / doi.org/10.29333/ejmste/108457

Suryaatamana, E., Darsa, U. A., Erlyane, A., \& Wartini, T. (1992). Paririmbon Sunda (Jawa Barat), Rosyadi (ed.)). Direktorat Jenderal Kebudayaan.

Syahrin, M. A., Turmudi, \& Puspita, E. (2016). Study ethnomathematics of aboge (alif, rebo, wage) calendar as determinant of the great days of Islam and traditional ceremony in Cirebon Kasepuhan Palace. AIP Conference Proceedings, 1708(1), 60009. https:/ / doi.org/10.1063/1.4941172

Turmudi, Juandi, D., Hidayat, A. S., Puspita, E., \& Ulum, A. S. (2016). Exploring ethno-mathematics: How the baduy of Indonesia use traditional mathematics skills in weaving. International Journal of Control Theory and Applications, 9(23), 323-339.

Turmudi, T. (2018). Kajian etnomatematika: Belajar matematika dengan melibatkan unsur budaya [Ethnomathematical studies: Learning mathematics involving cultural elements]. Prosiding Seminar Nasional Pendidikan Matematika Etnomatnesia - Proceedings of the National Seminar on Ethnomatnesian Mathematics Education.

Umbara, U., \& Suryadi, D. (2019). Re-Interpretation of mathematical literacy based on the teacher's perspective. International Journal of Instruction, 12(4), 789-806. https://doi.org/10.29333/iji.2019. $12450 a$

Umbara, U., Wahyudin, \& Prabawanto, S. (2019). Ethnomatematics: how does cigugur traditional community use palintangan on farming. Journal of Physics: Conference Series, 1265(1), 12025. https:// doi.org/10.1088/1742-6596/1265/1/012025

Van Den Heuvel-Panhuizen, M. (2003). The didactical use of models in realistic mathematics education: An example from a longitudinal trajectory on percentage. Educational Studies in Mathematics, 54(1), 9-35. https://doi.org/10.1023/B:EDUC. 0000005212.03219.dc

Vasquez, E. L. (2017). Ethnomathematics as an epistemological booster for investigating culture and pedagogical experience with the young offender or prison school communities. Journal of Education and Human Development, 6(2), 117-127. https://doi.org/10.15640/jehd.v6n2a13

Wahyudin, W. (2018). Etnomatematika Dan Pendidikan Matematika Multikultural [Ethnomatematics and Multicultural Mathematics Education]. Prosiding Seminar Nasional Pendidikan Matematika Etnomatnesia - Proceedings of the National Seminar on Ethnomatnesian Mathematics Education.

Yusuf, M. W., Ibrahim Saidu, I., \& Halliru, A. (2010). Ethnomathematics (A mathematical game in hausa culture). International Journal of Mathematical Science Education, 3(1), 36-42.

Zaslavsky, C. (1991). World cultures in the mathematics class. For the Learning of Mathematics, 11(2), 32-36.

Zaslavsky, C. (1994). "Africa Counts" and ethnomathematics. For the Learning of Mathematics, 14(2), 3-8.

Zawojewski, J. (2013). Problem solving versus modeling. In Modeling students' mathematical modeling 
competencies (pp. 237-243). Springer. https:/ / doi.org/10.1007/978-94-007-6271-8_20

Zeichner, K. M. (1996). Educating teachers to close the achievement gap: Issues of pedagogy, knowledge, and teacher preparation. Closing the Achievement
Gap: A Vision for Changing Beliefs and Practices, 5676.

Zheng, Y. (1999). Ethnomathematics and mathematics education. Journal of Guizhou Normal University (Natural Science), 4, 90-95.

\section{APPENDIX}

Matrix Results of the Determination of the Perfect Day in Building a House

\begin{tabular}{|c|c|c|c|c|c|}
\hline \multirow{2}{*}{ Hari and Naktu } & \multicolumn{5}{|c|}{ Pasaran and Naktu } \\
\hline & Manis (5) & Pahing (9) & Puhun (7) & Wage (4) & Kaliwon (8) \\
\hline Ahad (5) & 10 & 14 & 12 & 9 & 13 \\
\hline Senen (4) & 9 & 13 & 11 & 8 & 12 \\
\hline Salasa (3) & 8 & 12 & 10 & 7 & 11 \\
\hline Rebo (7) & 12 & 16 & 14 & 11 & 15 \\
\hline Kemis (8) & 13 & 17 & 15 & 12 & 16 \\
\hline Jumaah (6) & 11 & 15 & 13 & 10 & 14 \\
\hline Saptu (9) & 14 & 18 & 16 & 13 & 17 \\
\hline
\end{tabular}

Based on the matrix, it can be concluded that there are 35 pairs between the hari cycle and the pasaran cycle. The above matrix can make it easier to determine the day criteria for the Cigugur indigenous community. In one cycle, there are six days included in the Pati criteria (division 0, have value 10 \& 15), namely: ahad manis, salasa puhun, rebo kaliwon, kemis puhun, jumaah pahing dan jumaah wage. Hari with the Sri criteria (division 1, have value 11 \& 16) as many as seven days, namely: senen puhun, salasa kaliwon, rebo pahing, rebo wage, kemis kaliwon, jumaah manis, dan saptu puhun. There are eight days included in the Lungguh criteria (division 2, have value 7, 12 \& 17), namely: ahad puhun, senen kaliwon, salasa pahing, salasa wage, rebo manis, kemis pahing, kemis wage, dan saptu kaliwon. Meanwhile, the day is included in the Dunya criteria (division 3, have value 8,13 \& 18) as many as eight days, namely: ahad kaliwon, senen pahing, senen wage, salasa manis, kemis manis, jumaah puhun, saptu pahing dan saptu wage. Next, the day with Lara criteria (division 4, have value 9 \& 14) as many as six days, namely: ahad pahing, ahad wage, senen mans, rebo puhun, jumaah kaliwon, dan saptu manis.

\section{http://www.ejmste.com}

